\title{
Pleistocene climate and environment reconstruction by the paleomagnetic study of a loess-paleosol sequence (Cérna Valley, Vértesacsa, Hungary)
}

\section{Balázs Bradák}

Eötvös Loránd Geophysical Institute Paleomagnetic Laboratory, Budapest Department of Physical Geography, Eötvös Loránd University, Budapest

Erzsébet Horváth

Department of Physical Geography, Eötvös Loránd University, Budapest

\author{
Emő Márton \\ Eötvös Loránd Geophysical Institute \\ Paleomagnetic Laboratory, Budapest
}

\author{
Gábor Csillag \\ Geological Institute of Hungary, Budapest
}

Four paleosol layers indicating wet and moderate periods and five loess layers indicating dry and cold climate were separated by different methods. The following climate cycle model, based on the development of the sediment sequence created by the influence of climatic, geologic and geomorphologic phenomena, was established by detailed paleomagnetic studies (e.g. anisotropy of magnetic susceptibility (AMS), isothermal remanent magnetization (IRM), frequency dependence of magnetic susceptibility ( $\left.\kappa_{\mathrm{FD}}\right)$, etc.):

- A well-foliated magnetic fabric predominantly built up by multi-domain ferromagnetic minerals (magnetite, maghemite) was developed during the semi-arid (350-400 mm/y) and cold loessification period of the Pleistocene. The magnetic fabric can reflect the direction of dust deposition and/or the paleoslope.

- The accumulation period of dust was followed by the more humid $(650 \mathrm{~mm} / \mathrm{y})$ pedogenic period indicated by the enrichment of superparamagnetic minerals and by the disturbed or inverse magnetic fabric developed during pedogenesis by different processes (e.g. leaching and/or bioturbation).

- The third period following the pedogenic period is the humid erosional phase indicated by the finely layered reworked loess. The magnetic fabric built up by multi-domain ferro- and superparamagnetic minerals is characterized by better-aligned directions of principal susceptibilities than in the wind blown material. Sheet wash and other waterlogged surface processes appeared in the fabric of these layers. This process is possibly connected to sudden, rare yet significant events with high precipitation and absence of vegetation.

- The cycle was closed by the beginning of the next dust accumulation period.

Key words: magnetic susceptibility, anisotropy of magnetic susceptibility, frequency dependence of susceptibility, isothermal remanent magnetization, loess, paleosol, Pleistocene climate

Addresses: B. Bradák, E. Márton: H-1145 Budapest, Columbus u. 17-23, Hungary

E. Horváth: H-1117 Budapest, Pázmány P. sétány 1/C, Hungary

G. Csillag: H-1143 Budapest, Stefánia u. 14, Hungary

Received: February 1, 2009; accepted: May 3, 2009 


\section{Lithostratigraphy of the section and results of magnetic susceptibility measurements in the field}

The Cérna Valley section is located close to the village of Vértesacsa, exposed by a deep road cut in the loess in a NNE-SSW direction (Fig. 1A, B). The section contains the greatest amount of loess and paleosol layers in the area of the Vértes and Velence Hill region. It is here characterized from the bottom to the top.

The lowest part of the section is made up of typical loess characterized by manganese and secondary carbonate concretions (loess dolls, etc. - Fig. 1C, $\mathrm{L}_{5}$ ). This horizon is intercalated by a finely layered, possibly redeposited loess layer (Fig. 1C, $\mathrm{L}_{5 \mathrm{rd}}$ ).

A reddish paleosol (Fig. 1C, $\mathrm{P}_{4}$ ) layer was developed on this loess, indicating some degree of inclination in W-E direction. The upper part of this soil and the covering loess-like sediment are finely layered, possibly indicating redeposition and an erosional hiatus (Fig. 1C, $\mathrm{L}_{4 \mathrm{rd}}$ ). The redeposited material contains clayey paleosol and silty loess laminae as well. The paleosol laminae are absent in the upper part of this horizon. The redeposited loess is covered by a typical loess layer (Fig. 1C, $\mathrm{L}_{4}$ ). Dark brown paleosol (Fig. 1C, $\mathrm{P}_{3}$ ) was developed over the typical loess. The same sedimentological features finely laminated, redeposited loess-paleosol laminae - (Fig. 1C, $\mathrm{P}_{3 \text { trans }}$ and $\mathrm{L}_{3 \mathrm{rd}}$ ) - appeared at the upper part of this horizon, as well as on the upper part of the red paleosol (Fig. 1C, $\mathrm{P}_{4}$ ). The typical loess overlaying the redeposited material is the closing member of the climatic cycles, clearly identified in the loess section (Fig. 1C, $\mathrm{P}_{4}-\mathrm{L}_{4 \mathrm{rd}}-\mathrm{L}_{4}-\mathrm{P}_{3}-$ $\left.\mathrm{P}_{3 \text { trans }}-\mathrm{L}_{3 \mathrm{rd}}-\mathrm{L}_{3}\right)$.

The redeposited material is covered by the next typical loess layer, itself overlain by light brown paleosol $\left(\mathrm{P}_{2}\right)$. The $\mathrm{P}_{2}$ paleosol is overlain by a redeposited, finely layered material $\left(\mathrm{L}_{2 \mathrm{rd}}\right)$. The next, light gray paleosol layer $\left(\mathrm{P}_{1}\right)$ is clearly identified in Section A. The top of the section is a dynamically redeposited, unsorted, layered sediment.

In the field, a Kappameter KT-5 portable low field-susceptibility meter was used. The measuring intervals were $5 \mathrm{~cm}$, practically continuous (Fig. 1C).

The loess and paleosol layers of the profile can be characterized as 'Chinesetype loess'. The average susceptibility of typical loess layers is around $200 \times 10^{-6} \mathrm{SI}$ units. The horizons with carbonate concretions are characterized by lesser $\left(170-190 \times 10^{-6}\right.$ SI units), and the gleyic horizons by higher $\left(280-330 \times 10^{-6} \mathrm{SI}\right)$ susceptibility.

Susceptibility of the well-developed paleosols $\left(\mathrm{P}_{3}, \mathrm{P}_{4}\right)$ is characterized by $1200-1300 \times 10^{-6}$ SI units, while the weak horizons showed $600-900 \times 10^{-6}$ SI unitmagnetic susceptibility. The susceptibility of redeposited material is around $200-500 \times 10^{-6}$ SI units, depending on the sedimentological character of the material. 
Pleistocene climate and environment reconstruction of a loess-paleosol sequence 33
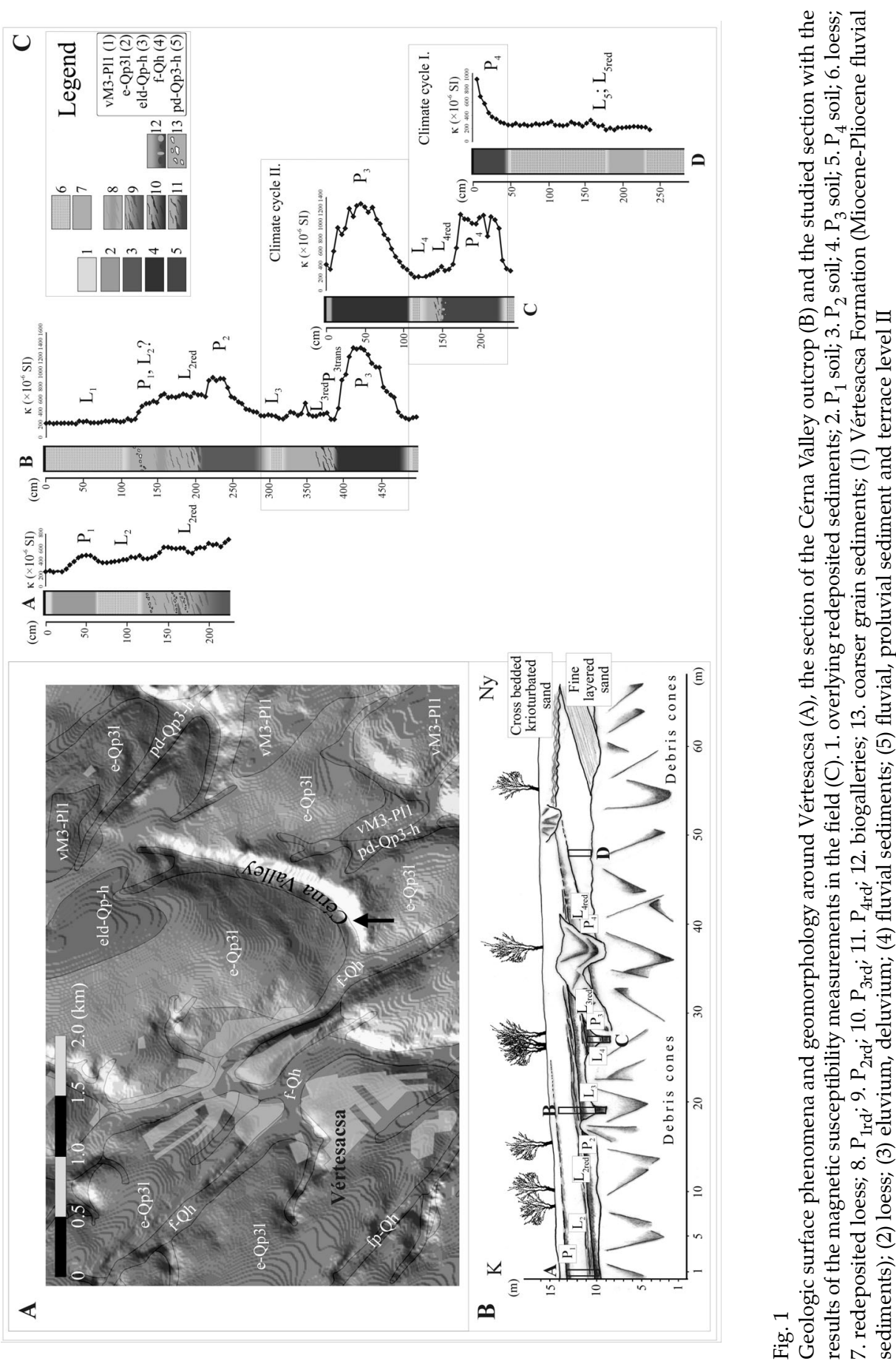

Central European Geology 52, 2009 


\section{Results of the laboratory magnetic measurements}

The measurements were carried out on the samples collected in cylindrical plastic boxes from the $\mathrm{P}_{3}$ and $\mathrm{P}_{4}$ paleosol layers, from the $\mathrm{P}_{3 \text { trans }}$ transient layer, from the typical $\mathrm{L}_{3}, \mathrm{~L}_{4}, \mathrm{~L}_{5}$ loess layers and from the laminated $\mathrm{L}_{3 \mathrm{rd}}, \mathrm{L}_{4 \mathrm{rd}}, \mathrm{L}_{5 \mathrm{rd}}$ layers.

Frequency-dependence susceptibility measurements $\left(\kappa_{F D}\right)$

The frequency dependence of magnetic susceptibility is the rate of the magnetic susceptibility of the sample measured at low $\left(460 \mathrm{~Hz} ; \kappa_{\mathrm{LF}}\right)$ and at high $\left(4.6 \mathrm{kHz}, \kappa_{\mathrm{HF}}\right)$ frequency $\left(\kappa_{\mathrm{FD}}=100\left(\kappa_{\mathrm{LF}}-\kappa_{\mathrm{HF}}\right) / \kappa_{\mathrm{LF}}\right)$. A Bartington MS2 was used to determine the low and the high field susceptibility of the samples. The frequency dependence of samples with susceptibility lower than $\kappa_{\mathrm{LF}}=20 \times 10^{-5}$ SI units was not determined, due to the high probability of error.

The $\kappa_{\mathrm{FD}}$ values of typical loess $\left(\mathrm{L}_{3}: 4.5 \%\right.$; $\mathrm{L}_{4}: 5.7 \%$ average) were similar to the typical loess samples studied from other European (e.g. Panaiotu et al. 2001) or Chinese (e.g. Zhu et al. 2004) sections. The $\kappa_{\mathrm{FD}}$ was higher in the redeposited loess ( $\mathrm{L}_{3 \text { áth }}: 9.2 \%$; $\mathrm{L}_{4 \mathrm{rd}}: 7.5 \%$; average) and in the transient level of soil ( $\mathrm{P}_{3 \text { átm: }}$ : 9.6\%; average). The highest $\kappa_{\mathrm{FD}}$ was measured in the paleosol samples (13.3 and $11.7 \%)$.

\section{Isothermal remanent magnetization (IRM)}

The magnetic components of the loess samples were identified by IRM measurements. This experiment started with the measurements of the natural remanent magnetization (NRM). Next, the samples were magnetized, using a pulse magnetizer, in fields from $20 \mathrm{mT}$ to $1000 \mathrm{mT}$ in the direction of axis $\mathrm{Z}$, in 17 steps. The acquired remanence was measured immediately after magnetization and 15-20 minutes later by a JR4 magnetometer (Fig. 2A, B).

We found that the paleosol samples $\left(\mathrm{P}_{3}, \mathrm{P}_{4}\right)$ and the transient $\mathrm{P}_{3 \text { trans }}$ had higher intensities and lower coercivities (saturation around 300-400 mT - Fig. 2A). The typical loess samples had lower intensities and higher coercivities (Fig. 2B). Evans and Heller (1994) observed similar phenomena, i.e. two main ferromagnetic mineral components in paleosols: they suggested that the (anti)ferromagnetic mineral component originated from dust fall (A - Fig. 2) and the ultra-fine magnetite originated from pedogenesis (B - Fig. 2C).

Following the above-described experiments, which eventually resulted in the acquisition of the saturation remanence (SIRM), the same samples were magnetized in a $300 \mathrm{mT}$ reverse field. The ratio (HIRM\%) calculated from the SIRM intensity and the one measured, after magnetizing the sample in the reverse field is indicative of the contribution from hard magnetic minerals with high coercivity (e.g. hematite - Robinson and Sahota 2000). The HIRM\% of our typical loess samples $\left(\mathrm{L}_{3}: 5.3 \%\right)$ was higher than the HIRM\% of paleosols $\left(\mathrm{P}_{3}\right.$ : 

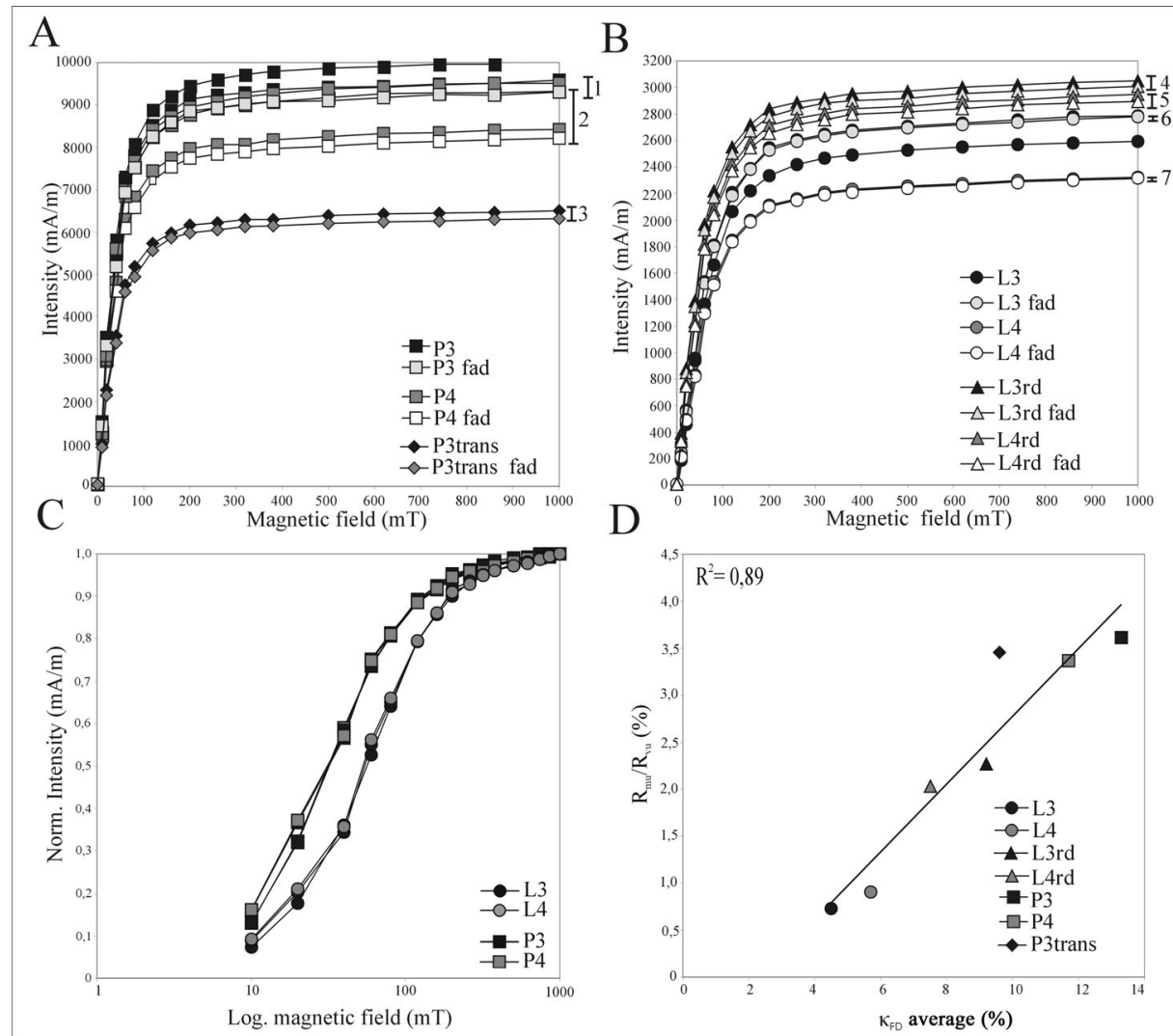

Fig. 2

Results of IRM evaluation of paleosols (A), loess (B); the difference between the IRM acquisition curve of loess and paleosol samples (after the diagram-type by Evans and Heller 1994, (C) and the regression of $\kappa_{\mathrm{FD}}$ vs. $\mathrm{R}_{\mathrm{mu}} / \mathrm{R}_{\mathrm{vu}}$ (D). 1. the $\mathrm{P}_{3}, 2$. the $\mathrm{P}_{4}, 3$. the $\mathrm{P}_{3 \text { trans }}, 4$. the $\mathrm{L}_{3 \mathrm{rd}}, 5$. the $\mathrm{L}_{4 \mathrm{rd}}, 6$. the $\mathrm{L}_{3}$ and 7. the $\mathrm{L}_{4}$ layer: the difference in the intensity after between measurement directly after magnetization and after $15-20 \mathrm{~min}$

$2.9 \% ; \mathrm{P}_{4}: 3.8$ and $4.0 \%$ ). Based on these results the presence of antiferromagnetic minerals is the possible cause of the behavior of typical loess samples (smaller intensity, larger coercivity - Fig. 2C).

The difference between the intensities of samples measured immediately after magnetization and after 20 minutes is indicative of superparamagnetic minerals, since their remanence decays very rapidly after removing the magnetizing field. The ratio was highest in the paleosol samples $\left(\mathrm{P}_{3 \text { trans }}: 3.5 \% ; \mathrm{P}_{3}: 3.6 \%\right.$ and $\mathrm{P}_{4}$ : $3.4 \%)$, lower in the redeposited loess $\left(\mathrm{L}_{3 \mathrm{rd}}: 2.3 \%\right.$; $\left.\mathrm{L}_{4 \mathrm{rd}}: 2.0 \%\right)$ and lowest in typical loess samples $\left(\mathrm{L}_{3}: 0.7 \% ; \mathrm{L}_{4}: 0.9 \%\right)$. The ratio of the two intensities correlates very well with the superparamagnetic contribution calculated from the measurements of the frequency-dependent susceptibility. 


\section{Cisowski test}

Apart from the superparamagnetic minerals, the samples may contain multi (MD) or single domain (SD) ferromagnetic minerals, or a mixture of the two. Cisowski (1981) suggested a test which distinguishes between MD and SD grains. The first part of the experiment is the step-wise magnetization of the samples. The second part is the demagnetization of the same samples in an alternating field. The SIRM of the loess samples of the present study were demagnetized, in alternating fields of 3 to $100 \mathrm{mT}$ (using a Demag 01-79 demagnetizer) in 18 steps and the intensity was measured after each step. The IRM and AF curves have a point of intersection, which is characteristic of the grain size composition of the sample (Fig. 3).

In the studied collection, both the loess and the paleosol samples were found to contain multi-domain (MD) magnetic minerals based on the value of $\mathrm{R}$ $(0.25-0.35)$ and the HRC (<50 mT - Fig. 3).

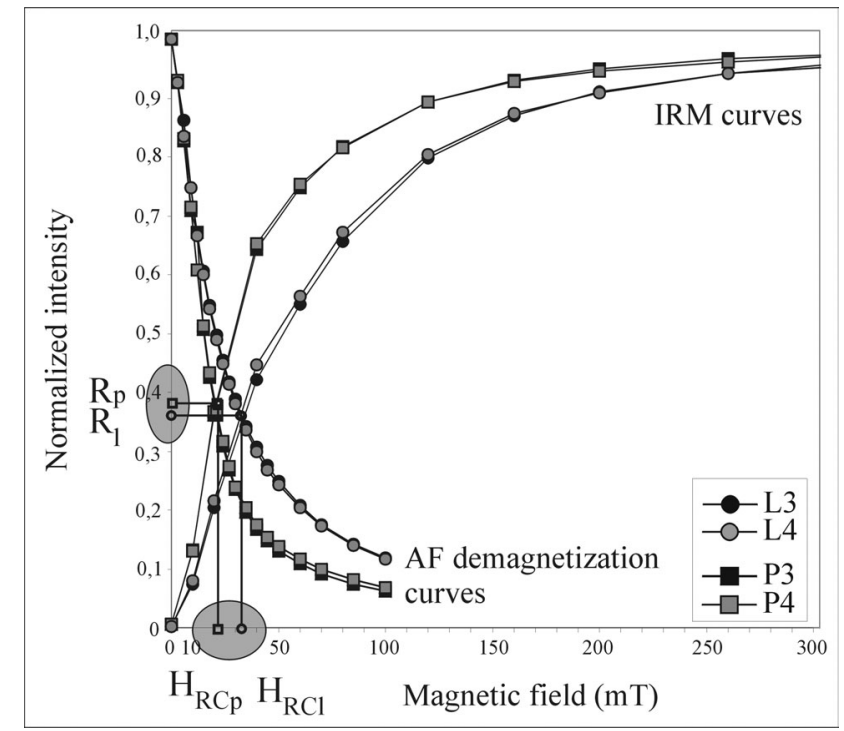

Fig. 3

Results of the Cisowski test

\section{Anisotropy of magnetic susceptibility (AMS)}

The directional magnetic susceptibilities of the samples were measured in 15 positions using a KLY-2 Kappabridge instrument. The value and direction (inclination and declination) of the principal susceptibilities $\left(\kappa_{\max }, \kappa_{\text {int }}, \kappa_{\min }\right)$ were determined from the measurements by computer analysis. The foliation $(\mathrm{F})$, lineation (L) and degree of anisotropy $(\mathrm{P})$ were defined by the formula of Balsley and Buddington (1960), Jelinek (1981), Nagata (1961), and Stacey et al. (1960) and plotted on a Flinn and Jelinek diagram (Fig. 4). The directions of the principal 

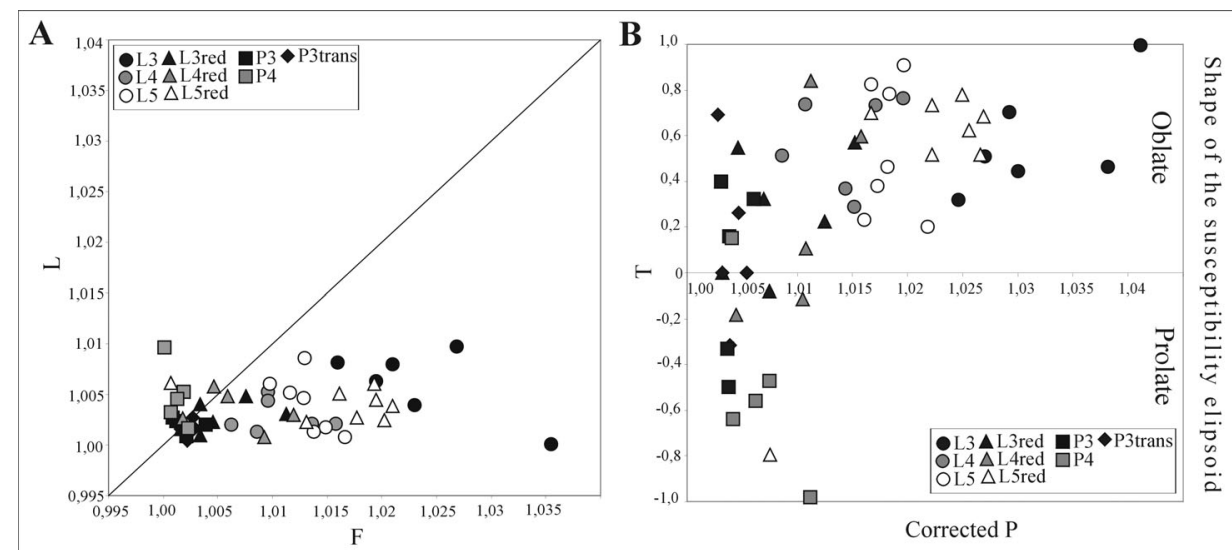

Fig. 4

Presentation of AMS results on Flyn (A) and Jelinek diagram (B)

susceptibilities were plotted on stereographic projections in the geographical coordinate system (Fig. 5).

The magnetic fabric of loess samples were mainly foliated (Fig. 4A). The degree of foliation was highest in the typical loess samples, smaller in the redeposited loess samples, and the lowest in the paleosols. The susceptibility ellipsoid is typically oblate for the typical loess and tends to become triaxial in redeposited loess and paleosol samples (Fig. 4B).

Concerning the directions, the minimum susceptibilities of the typical loess samples cluster around the bedding pole $\left(\kappa_{\min }\right.$ inclination around $\left.70-90^{\circ}\right)$, reflecting near-horizontal deposition and compaction. However, there are some exceptions, namely $\mathrm{L}_{3}$ and $\mathrm{L}_{5}$, which must represent the accumulation of eolian dust on a slope (Rees 1966; Rees and Woodal 1975; Ellwood and Howard 1981). The direction of the maximum susceptibility $\left(\kappa_{\max }\right)$, on the other hand, may reflect the direction of paleotransport. In the typical loess samples, the direction of the maximum susceptibility corresponds to the direction of the transport. There are cases, however, namely of the redeposited varieties of the loess, where the maxima are perpendicular to the flow, suggesting a high energy environment $\left(\mathrm{L}_{3 \mathrm{rd}}, \mathrm{L}_{4 \mathrm{rd}} ;\right.$ Fig. 5C)

The directions of maximum and minimum susceptibilities are scattered in the fine-layered redeposited loess ( $\mathrm{L}_{5 \mathrm{rd}} ;$ Fig. $\left.5 \mathrm{~B}\right)$.

The $\mathrm{P}_{3}$ and $\mathrm{P}_{4}$ paleosols had an inverse magnetic fabric, i.e. not the $\kappa_{\min }$ : the $\kappa_{\max }$ directions clustering around the bedding pole (Fig. 5D), suggesting that the original magnetic fabric was overprinted during a later pedogenic process.

The transition layer of $\mathrm{P}_{3}$ paleosol has an oriented fabric, but this fits neither the fabric of the typical loess nor that of the inverse fabric of paleosol (Fig. 5E). 
38 B. Bradák et al.

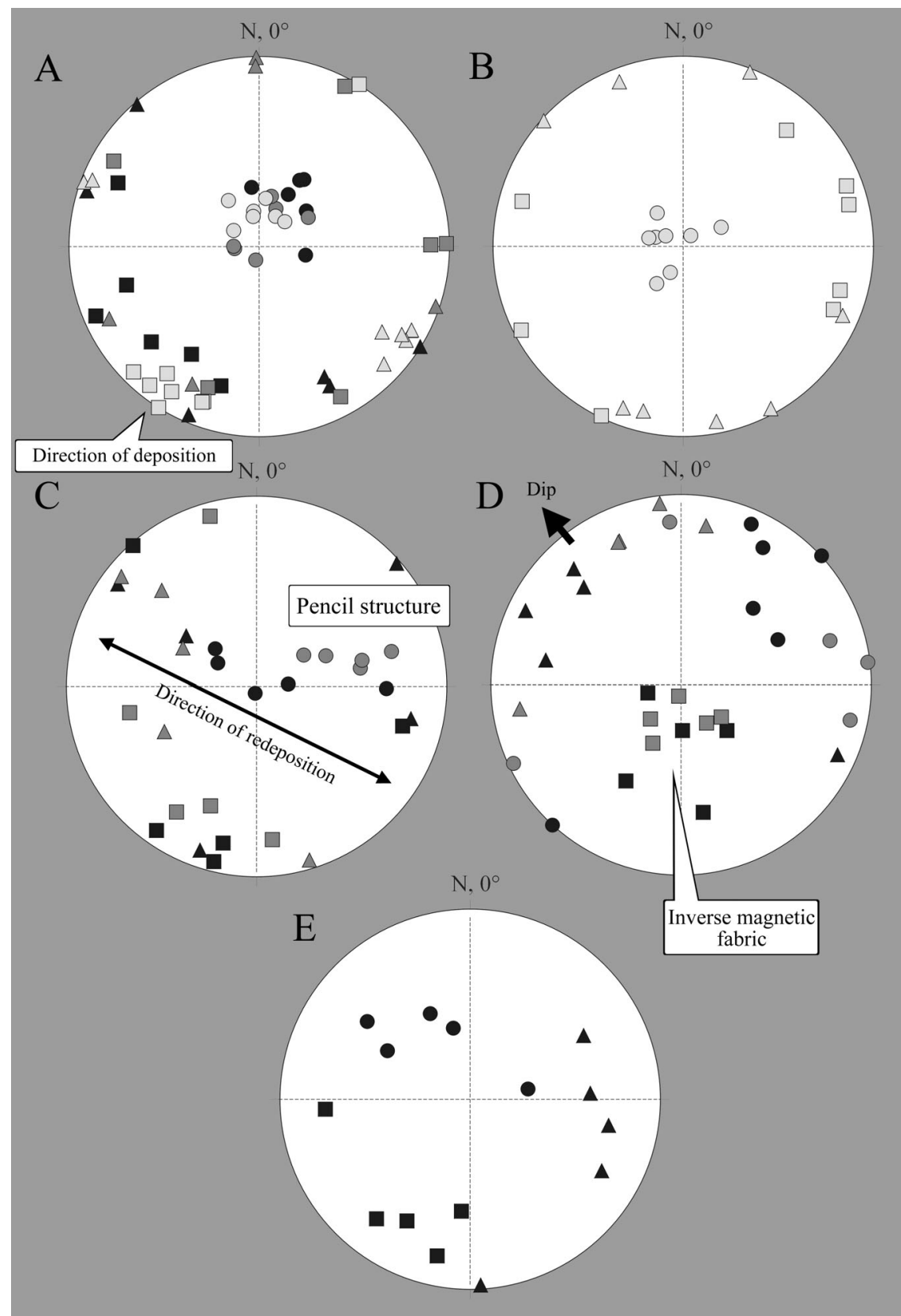

Fig. 5

Examples of typical magnetic fabric on stereographical plot

Central European Geology 52, 2009 


\section{Characterization of the sediments and paleosols of the Cérna Valley section by magnetic parameters}

At the Cérna Valley section five cold and dry glacial (stadial) and four moderate and wet interglacial (interstadial) Pleistocene climate phases were separated in the field, with the aid of in situ magnetic susceptibility measurements. The section could be further subdivided and more information about the Pleistocene paleoenvironment obtained, as a result of a laboratory paleomagnetic study.

The typical loess is characterized by low magnetic susceptibility, due to the small amount of coarse-grained multi-domain ferromagnetic mineral. In addition to the dominant magnetite, the presence of hematite is also indicated by the high HIRM\% (Kukla et al. 1988; Forster and Heller 1997). The typical (wind-blown) loess has a well-directed, foliated magnetic fabric (Fig. 3). The minima usually cluster around the bedding pole, indicating a quiet environment during deposition and/or compaction during lithogenesis (diagenesis). The few cases, where the minima deviate considerably from the vertical can be attributed to deposition on a NE-SW paleoslope.

The $\kappa_{\mathrm{FD}}$ of the redeposited loess is higher than that of typical loess, probably due to the paleosol laminae which have higher susceptibilities and contain superparamagnetic authigenic minerals (higher frequency dependence susceptibility). The characteristic magnetic fabric of $\mathrm{L}_{3 \mathrm{rd}}$ and $\mathrm{L}_{4 \mathrm{rd}}$ samples indicate turbulent flow: the maxima are perpendicular to the direction of transport (Fig. $5 \mathrm{C}, \mathrm{NW} / \mathrm{SE}$ ), indicating that the elongated magnetic grains were rolled laterally (Tarling and Hrouda 1993).

The paleosol layers are characterized by the highest magnetic susceptibility, due to the higher concentration of multi-domain ferromagnetic grains and the superparamagnetic component (Thompson and Oldfield 1986; Forster et al. 1994; Eyre 1997; Worm 1998). The superparamagnetic minerals were probably generated during pedogenesis (e.g. by decay of plant tissue; Meng et al. 1997).

The paleoprecipitation of the different climate phases was estimated by the result of frequency dependence of magnetic susceptibility measurements, applying the Panaiotu et al. (2001) method (Fig. 6). In the interglacial or interstadial periods there was $646 \mathrm{~mm} / \mathrm{y}$ precipitation (during the pedogenesis of P3 soil) and $636 \mathrm{~mm} / \mathrm{y}$ precipitation (during the pedogenesis of $\mathrm{P} 4$ soil). As opposed to the wet and moderate climate there was $360-370 \mathrm{~mm} / \mathrm{y}$ precipitation during the glacial or stadial period indicated by wind-blown loess (semiarid climate, steppe).

Inverse magnetic fabric was identified in the magnetic fabric of P3 and P4 paleosols. This is possibly linked to leaching during pedogenesis.

Finally, the following climate cycle model can be outlined by the results of different paleomagnetic methods (Fig. 7):

- During the semiarid (360-370 $\mathrm{mm} / \mathrm{y}$ precipitation), cold, glacial (stadial) climate the dust accumulated on a paleoslope of a valley or on the slope of a pediment (deviation of $\kappa_{\min }$ inclination from $90^{\circ}$ ) from a NE or SW direction 


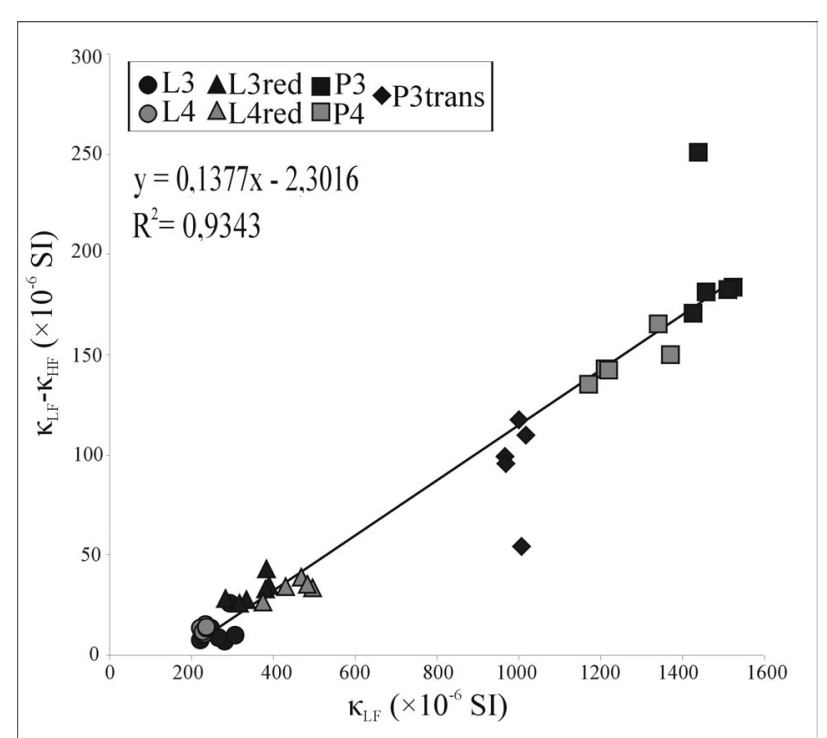

Fig. 6

Estimation of the paleoprecipitation by regression analysis

(declination of $\left.\kappa_{\max }\right)$. The magnetic fabric of wind blown or typical loess $\left(\mathrm{L}_{3}, \mathrm{~L}_{4}\right)$ indicates a quiet environment during deposition and compaction after the accumulation of dust. Sometimes the diagenetisized magnetic fabric of typical loess is disturbed by some surface processes characterized by weak transport energy (solifluction or sheet wash $-\mathrm{L}_{5}$ ).

- The accumulation period of dust was followed by the more humid $(650 \mathrm{~mm} / \mathrm{y}$ precipitation) interglacial (interstadial) phase. During the pedogenic period the magnetic fabric of loess was altered: lineated inverse magnetic fabric (?max inclination around $90^{\circ}$ ) evolved through pedogenic processes (e.g. leaching, bioturbation) and the superparamagnetic component is represented by authigenic minerals created during pedogenesis.

- The third period was the humid erosional phase at the beginning of glacial (stadial) phase. The higher, turbulent flow, indicated by the pencil magnetic fabric $\left(\kappa_{\min }, \kappa_{\text {int }}\right)$ of $\mathrm{L}_{3 \text { red }}$ and $\mathrm{L}_{4 \mathrm{red}}$ layers, redeposited the material on a slope (deviation of $\kappa_{\min }$ inclination from $90^{\circ}$ ) from the NW. The latter, water-logged surface processes with higher energy were possibly connected to rare, sudden yet significant events with high precipitation and absence of vegetation.

\section{Acknowledgement}

The study of the Cérna Valley loess section was supported by the Hungarian Scientific Research Found (OTKA) grant No. K62478. 
Fig. 7

Climate cycle model

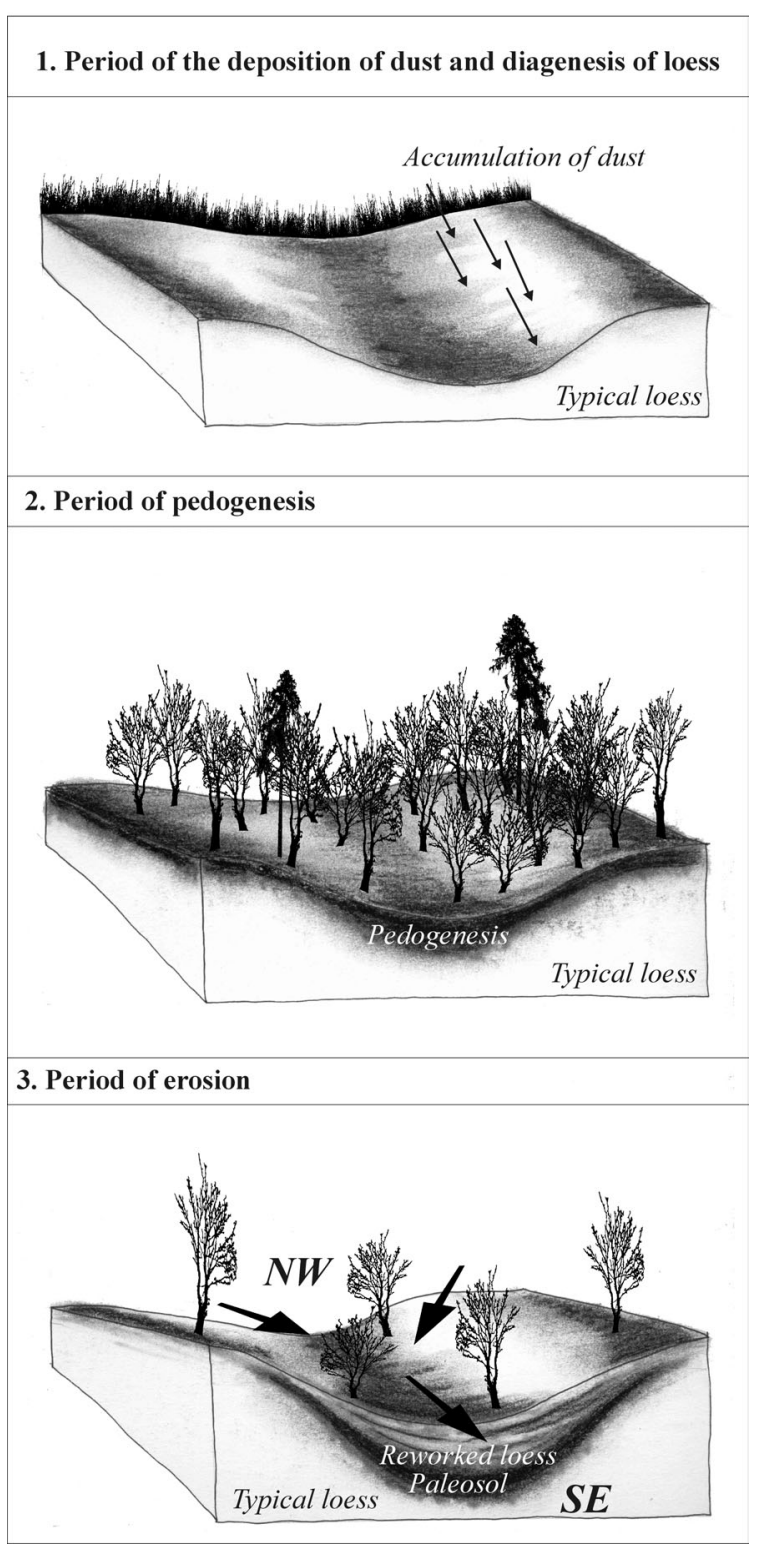




\section{References}

Balsley, J.R., A.F. Buddington 1960: Magnetic Susceptibility Anisotropy and Fabric of Some Adirondack Granites and Orthogneisses. - American Journal of Science 258-A, 6-20. In: Hrouda, F. 1982: Magnetic anisotropy of rock and its application in geology and geophysics Geophysical Survey 5, pp. 37-82.

Cisowski, S. 1981: Interacting vs. non-interacting single domain behaviour in natural and synthetic samples. - Physics of the Earth and Planetary Interiors 26, pp. 56-62.

Ellwood, B.B., J.H. Howard 1981: Magnetic fabric development in an experimentally produced barchan dune. - Journal of Sedimentology - Petrology 51, pp. 97-100.

Eyre, J. 1997: Frequency dependence of magnetic susceptibility for populations of single-domaingrains. - Geophysical Journal International, 129, pp. 209-211.

Evans, M.E., F. Heller 1994: Magnetic enhancement and paleoclimate: study of a loess/paleosol couplet across the Loess Plateau of China. - Geophysical Journal International, 117, pp. 257-264.

Forster, T., M.E. Evans, F. Heller 1994: The frequency dependence of low field susceptibility in loess sediments. - Geophysical Journal International, 118, pp. 636-642.

Forster, T., F. Heller 1997: Magnetic enhancement path in loess sediments from Tajikistan, China and Hungary. - Geophys. Res. Lett., 24, pp. 17-20.

Jelinek, V. 1981: Characterization of magnetic fabric of rocks. - Tectonophysics, 79, pp. 63-67.

Kukla, G., F. Heller, X.M. Liu, T.C. Xu, T.S. Liu, Z.S. An 1988: Pleistocene climate in China dated by magnetic susceptibility. - Geology, 16, pp. 811-814.

Maher, B., R. Thompson 1995: Paleorainfall reconstruction from pedogenic magnetic susceptibility variations in the Chinese Loess and Paleosols. - Quaternary Research, 44, pp. 383-391.

Meng, X., E. Derbyshire, R.A. Kemp 1997: Origin of the magnetic susceptibility signal in Chinese loess. - Quaternary Science Reviews, 16, pp. 833-839.

Nagata, T. 1961: Rock Magnetism. - Maruzen, Tokyo, 320 p.

Panaiotu, C.G., E.C. Panaiotu, A. Grama, C. Necula 2001: Paleoclimatic record from loess-paleosol profile in south-eastern Romania. - Physics and Chemistry of the Earth, 26/11-12, pp. 893-898.

Potter, D.K., A. Stephenson 1988: Single-domain particles in rocks and magnetic fabric analysis. Geophysical Research Letters, 15, pp. 1097-1100.

Rees, A.I. 1966: The effect of depositional slopes on the anisotropy of magnetic susceptibility of laboratory deposited sands. - Journal of Geology, 74, pp. 856-867.

Rees, A.I., W.A. Woodal 1975: The magnetic fabric of some laboratory-deposited sediments. - Earth and Planetary Science Letters, 25, pp. 121-130.

Robinson, S.G., J.TS. Sahota 2000: Rock-magnetic characterization of early, redoxomorphic diagenesis in turbidic sediments from the Madeira Abyssal Plain. - Sedimentology, 47, pp. 367-394.

Stacey, F.D., G. Joplin, J. Lindsay 1960: Magnetic Anisotropy and Fabric of Some Foliated Rock from S.E. Australia. - Geofiz. Pura. Appl., 47, pp. 30-40. In: Hrouda, F. 1982: Magnetic anisotropy of rock and its application in geology and geophysics. - Geophysical Survey, 5, pp. 37-82.

Tarling, D.H., F. Hrouda. 1993: The Magnetic Anisotropy of Rock. - Chapman and Hall, London, Glasgow, New York, Tokyo, Melbourne, Madras, 217 p.

Thompson, R., M. Oldfield 1986: Environmental Magnetism. - London, Allen and Unwin. 227 p.

Worm, H.-U. 1998: On the superparamagnetic-stable single domain transition for magnetite, and frequency dependence of susceptibility. - Geophysical Journal International, 133, pp. 201-206.

Zhu, R., Q. Liu, M.J. Jackson 2004: Paleoenvironmental significance of the magnetic fabric in Chinese loess-paleosols since the last interglacial $(<130 \mathrm{ka})$. - Earth and Planetary Science Letters, 221, pp. 55-69. 